\title{
Testing of Rounded Valley Aggregate in Concrete Mix in Comparison with Crushed Limestone Aggregate
}

\author{
Mohmd Sarireh ${ }^{1}$ \\ 1 Department of Civil Engineering, Faculty of Engineering, Tafila Technical University, Tafila, 66110, Jordan \\ e-mail:m.sarireh@gmail.com
}

\begin{abstract}
Round valley aggregate RVA is a natural source of aggregate that is found in Tafila in Jordan. For current research, RVA from Al-Hasa valley was considered for testing with crushed limestone aggregate (CLA) from Karak and Tafila sources. 39 samples were collected through the valley at the joint with the lake of Al-Tanour Dam in Tafila. Samples of RVA and CLA were tested and concrete mix at 15, 20, and $25 \mathrm{MPa}$. ANOVA analysis was conducted to test means' differences in aggregate and concrete properties. Results showed that RVVA has no significant difference in means' properties. While RVA has significant differences when with CLA from Karak and Tafila. Results of ANOVA showed that there is a significant difference in the properties of fresh and hardened concrete for 15 and $25 \mathrm{MPa}$ concrete grades. While significant difference is neglected for $20 \mathrm{MPa}$ concrete grade. Consequently, RVA can be used for concrete mix as CLA.
\end{abstract}

Keywords: rounded valley aggregate, concrete mix design, density, strength

\section{INTRODUCTION}

Aggregate occupies $75 \%$ of concrete volume and gives volumes stability to concrete and responsible mainly for strength. Concrete mix in all its grades consumes crushed limestone aggregate (CLA) that mined in a continuous operation from local stations and plants in huge quantities and transported to farther sites, so rounded valley aggregate (RVA) becomes an important source for aggregate surface mining and concrete production [1]. The use of RVA is more economical and effective in achieving the desired concrete compressive strength and other properties of concrete. RVA is more effective in mining that has less production waste, and can be transported locally for short-trip distances. RVA has competitive properties such as the less absorption and less abrasion and more uniform fineness modulus.

The trials to improve concrete performance and quality are essential steps for the whole development of building and construction process through technology and materials to avoid overruns in time and cost [2]. The development process can be achieved through the development on cement the binder agent, natural and/or artificial fibers, or through the use of coarse and fine aggregates from new sources. The effect of mineralogical nature, and/or the effect of aggregate shape and texture are highly affect concrete properties. Several studies had showed that the effect of physical and mineralogical properties of aggregate, also affect directly the properties of some mixture types such as cementacious (cement and concrete) and asphaltic mixture $[3,4,5,6]$.

Even CLA contributes higher in concrete compressive strength, but RVA also contributes more in other properties of fresh concrete such as workability and considerable high slump value at low w/c ratio, and low water absorption [7] that will use less mixing water to improve compressive strength and other strength parameters of concrete. RVA can improve compressive strength, flexural tensile and splitting strengths when elaborated in laboratory conditions by $(26 \%, 46 \%$, $38 \%$ ) respectively. And economically, RVA is cost less than crushed aggregate, so concrete produced will be cheaper [8]. 
The current study aims to test the use of RVA as a local construction material in concrete and construction industry through the elaboration of RVA properties according considering the specific size gradation that can suit different uses [9]. A comparable methodology for testing RVA and CLA is employed using ANOVA analysis for properties of aggregate and concrete mix. Specific gravity, absorption, abrasion, in addition to the fresh and hardened properties of concrete on 15 , 20, and $25 \mathrm{MPa}$ grades.

One-way ANOVA analysis can be employed with the purpose of comparing means of population of several independent groups or samples. Statistical parameters such level of significance alpha $(\alpha)$, degree of freedom, means standard deviations, and size of groups or samples are essential information in ANOVA test or analysis [10].

\section{MATERIALS AND METHODS}

\section{Cement}

According to [11], ordinary Portland cement type I (OPC-I) is used in normal applications for concrete production. Lafarge Cement Cooperation Factory in Tafila at South of Jordan produces cement and concrete for different uses and applications. The hydraulic (OPC-I) cement produced by pulverizing clinker primarily consisting of hydraulic calcium silicates, and containing one or more types of calcium sulphate as an interground addition. Also, blended cement refers to other materials which may be added or blended in the production of hydraulic cement. [12] uses the term for a hydraulic cement consisting of Portland cement and other appropriate of inorganic materials. Lafarge cement has the chemical analysis that is shown in Table 1.

Physical properties such as fineness of cement, soundness or expansion, and initial setting time of cement are presented in Table 2 for Lafarge cement that was used in concrete production.

\section{Mixing water}

Mixing water is the tap water that is usually used in concrete mix depending on $\mathrm{w} / \mathrm{c}$ ratio for specific concrete strength [14]. There is a relation between the 28-day compressive strength and $\mathrm{w} / \mathrm{c}$ ratio that is highly affect the compressive strength of concrete [15].
Table 1. Chemical properties of ordinary Portland cement $[11,13]$

\begin{tabular}{|l|c|c|}
\hline \multirow{2}{*}{ Chemical requirements } & \multicolumn{2}{|c|}{ Results } \\
\cline { 2 - 3 } & Min. & Max. \\
\hline Ignition loss & 0.89 & 1.94 \\
\hline Insoluble residue & 0.49 & 1.7 \\
\hline $\mathrm{MgO}$ & 1.83 & 3.83 \\
\hline $\mathrm{SO}_{3}$ & 2.67 & 3.5 \\
\hline $\mathrm{Chloride} \mathrm{content}$ & 0.01 & 0.03 \\
\hline $\mathrm{CaO}$ & 60.89 & 64.9 \\
\hline $\mathrm{SiO}_{2}$ & 17.81 & 20.77 \\
\hline $\mathrm{Al}_{2} \mathrm{O}_{3}$ & 4.12 & 6.02 \\
\hline $\mathrm{Fe}_{2} \mathrm{O}_{3}$ & 2.97 & 5.44 \\
\hline $\mathrm{K}_{2} \mathrm{O}$ & 0.6 & 1.02 \\
\hline Free lime & 0.75 & 2.56 \\
\hline
\end{tabular}

Table 2. Physical properties of ordinary Portland cement [13]

\begin{tabular}{|l|c|c|}
\hline \multirow{2}{*}{ Physical requirements } & \multicolumn{2}{c|}{ Results } \\
\cline { 2 - 3 } & Min. & Max. \\
\hline Fineness (Blaine) $\left(\mathrm{cm}^{2} / \mathrm{g}\right)$ & 4188 & 5020 \\
\hline Soundness (expansion) $(\mathrm{mm})$ & 1.5 & 2.5 \\
\hline Initial setting time (min) & 120 & 180 \\
\hline
\end{tabular}

\section{Aggregate}

Since aggregate composes about $75 \%$ of concrete volume, aggregate affects the properties of concrete [16]. The shape of aggregate affects concrete workability in fresh stage and compressive strength in hardened stage and finally durability of concrete [2]. Elongation flatness factors, shape factor, sphericity, and roundness are factors affect mostly concrete properties. The behavior of fresh concrete is measured by slump test and density of concrete. In addition to water and cement contents that affect concrete strength also [17].

Coarse and fine CLA were chosen to be transferred from local crusher-plants in Tafila and Karak at South of Jordan. Coarse and fine RVA were chosen from Al-Hasa valley at the point of intersection Al-Hasa valley with the lake of Tanour Dam at Tafila. CLA and RVA were separated to the coarse size of (19-10 mm) size ([18] and [19]. Medium size of CLA and RVA also selected from the same source of local surface mining plants in Karak and Tafila with the size of $(10-4.75 \mathrm{~mm})$ [20]. Natural fine sand was used in all concrete mixes of size gradation of (2.36-0.3 $\mathrm{mm}$ ) [21]. Sieve analysis for coarse and medium aggregate and fine sand is covered by [22]. Concrete mix design and analysis were conducted in 
order to find the appropriate ratio of mixing materials of water, cement, and aggregate [23] and [24]. Table 3 presents the approximate concrete mix proportions in concrete mix design on 15,20, and $25 \mathrm{MPa}$. Specific gravity was considered to calculate the volumes of aggregate of CLA and RVA.

\section{Methods}

Current research bases on testing the physical and mechanical properties of aggregate samples that were collected to produce concrete mix. CLA was collected from local crusher-plants in Tafila and Karak, and RVA was collected from AL-Hasa valley at the joint with the lake of Tanour Dam at Tafila. Aggregate tests included specific gravity, fineness modulus, absorption, and abrasion. Concrete tests included slump, density, compressive strength, tensile strength, and modulus of rupture. Means, standard deviations, and sum of squared errors were calculated in order to use ANOVA analysis test to evaluate the significance difference in means between properties of aggregate and concrete samples. ANOVA test for independent measures is designed to compare the means of three or more independent samples (treatments). The analysis can be successfully employed to test the effect of treatment on properties of aggregate and concrete mix considering CLA from Tafila and Karak, and RVA. The 15,20 , and $25 \mathrm{MPa}$ grades of concrete mix were designed on the appropriate $\mathrm{w} / \mathrm{c}$ ratio, cement content, and aggregate properties and its gradation for CLA and RVA. Concrete properties were tested on fresh-phase and on hardened phase at 7-, 14-, and 28-day [26] and [27]. Representatives of 39 samples of fine and coarse RVA were tested for specific gravity, abrasion, and absorption. Then samples of CLA and RVA were tested and compared using ANOVA analysis technique considering the three sources as levels of treatment [28]. ANOVA analysis can be applied successfully to predict differences in means of processes, operations, and products depending on levels of treatment [29] and [30].

\section{RESULTS}

\section{Tests of fine aggregates}

\section{Dry specific gravity}

Table 4 presents dry density values of fine RVA that were collected from left, middle, and right sides of valley through 13 stations in a total number of 39 samples. Results showed means, standard deviation, and required parameters to conduct ANOVA analysis. Results of ANOVA showed that samples of fine RVA are uniform, and there is no difference in dry specific gravity and the samples are representative.

ANOVA analysis was applied to test differences in the results of dry specific gravity of fine aggregate samples (RVA, CLA from Karak and

Table 3. Concrete mix proportions [25]

\begin{tabular}{|c|c|c|c|c|c|}
\hline \multirow{2}{*}{$\begin{array}{c}\text { Concrete } \\
\text { grade }(\mathrm{MPa})\end{array}$} & \multicolumn{5}{|c|}{ Constituents content $\left(\mathrm{kg} / \mathrm{m}^{3}\right)$} \\
\cline { 2 - 6 } & Cement & Fine sand & Medium & Coarse & Water \\
\hline 15 & 265 & 761 & 571 & 572 & 240 \\
\hline 20 & 306 & 745 & 559 & 560 & 267 \\
\hline 25 & 360 & 723 & 542 & 543 & 344 \\
\hline
\end{tabular}

Table 4. Statistical analysis of dry specific gravity of fine RVA

\begin{tabular}{|c|c|c|c|c|}
\hline Statistical parameters & Right & Mid & Left & Total \\
\hline $\mathrm{N}$ & 13 & 13 & 13 & 39 \\
\hline$\Sigma x$ & 30.483 & 31.229 & 30.382 & 92.093 \\
\hline Mean & 2.345 & 2.402 & 2.337 & 2.361 \\
\hline$\Sigma \times 2$ & 71.56 & 75.093 & 71.075 & 217.727 \\
\hline Standard Deviation & 0.083 & 0.079 & 0.077 & 0.083 \\
\hline \multicolumn{5}{|c|}{ Results details } \\
\hline Source & SS & df & MS & \\
\hline Between treatments & 0.033 & 2 & 0.017 & $F=2.6$ \\
\hline Within treatment & 0.228 & 36 & 0.006 & \\
\hline Total & 0.261 & 38 & & \\
\hline
\end{tabular}

* The f-ratio value is 2.6 . The $p$-value is 0.0882 . The result is not significant at $p<0.05$. 
Tafila), they are significantly different depending on their means, standard deviation considering significance level $\alpha=0.05$. Each type of aggregate can be used significantly in concrete mix production. So, the null hypothesis Ho that specifies $(\mu 1=\mu 2=\mu 3)$ is rejected, and the alternate hypothesis $\mathrm{Ha}(\mu 1 \neq \mu 2 \neq \mu 3)$ is accepted. Results are shown in Table 5.

\section{Saturated surface dry specific gravity}

Table 6 presents the statistical parameters of saturated surface dry (SSD) specific gravity of fine RVA, 39 samples were collected from the valley for 13 stations on right, middle, and left sides of the valley. ANOVA analysis showed that there is no significant difference between SSD specific gravity of the fine RVA.

By applying ANOVA analysis to test differences in SSD specific gravity of fine RVA and CLA for Karak and Tafila, considering significance level $\alpha=0.05$, the null hypothesis $\mathrm{H} 0(\mu 1=$ $\mu 2=\mu 3)$ is rejected, and the alternate hypothesis H1 $(\mu 1 \neq \mu 2 \neq \mu 3)$ is accepted. Table 7 presents the statistical parameters for the three groups.

\section{Apparent specific gravity}

Table 8 presents the statistical calculations for the apparent specific gravity of fine RVA for the 13 stations ( 39 samples) that extended on the right, middle, and left sides of the valley. ANOVA analysis showed that the means of samples have no significant differences and all samples are representative to be used as fine RVA in concrete mix.

Also, differences between means of RVA and CLA were tested and results showed that considering significance level $\alpha=0.05$, each type of aggregate can be used significantly in concrete mix production. The null hypothesis $\mathrm{H} 0(\mu 1=\mu 2=$ $\mu 3)$ is rejected, and the alternate hypothesis $\mathrm{Ha}$ $(\mu 1 \neq \mu 2 \neq \mu 3)$ is accepted. Results are presented in Table 9.

\section{Tests of coarse aggregate}

\section{Dry specific gravity}

Table 10 presents data and test for dry specific gravity of coarse RVA that were collected from the valley. Coarse aggregates were collected and taken from aggregate passes 3/4" sieve size and retains on $3 / 8$ " sieve size. Results showed that there is no significant difference between means of samples collected and all samples are representative for coarse RVA to be used in concrete mix.

By applying ANOVA analysis on the three groups of coarse aggregate samples (RVA, CLA /

Table 5. Dry specific gravity of fine RVA and CL A

\begin{tabular}{|c|c|c|c|c|c|c|c|c|}
\hline \multicolumn{3}{|c|}{ RVA } & \multicolumn{3}{c|}{ CLA/Karak } & \multicolumn{3}{c|}{ CLA/Tafila } \\
\hline Average & Std. & $\mathrm{N}$ & Average & Std. & $\mathrm{N}$ & Average & Std. & $\mathrm{N}$ \\
\hline 2.361 & 0.083 & 13 & 2.664 & 0.076 & 10 & 2.566 & 0.065 & 10 \\
\hline
\end{tabular}

Table 6. Statistical values of SSD specific gravity of fine RVA

\begin{tabular}{|c|c|c|c|c|}
\hline Statistical parameters & Right & Mid & Left & Total \\
\hline $\mathrm{N}$ & 13 & 13 & 13 & 39 \\
\hline$\Sigma \mathrm{x}$ & 32.012 & 32.224 & 32.208 & 96.264 \\
\hline Mean & 2.462 & 2.479 & 2.464 & 2.468 \\
\hline$\Sigma \times 2$ & 78.868 & 79.898 & 78.931 & 237.696 \\
\hline Standard Deviation & 0.059 & 0.042 & 0.043 & 0.048 \\
\hline \multicolumn{5}{|c|}{ Results details } \\
\hline Source & $\mathrm{SS}$ & $\mathrm{df}$ & $\mathrm{MS}$ & $\mathrm{F}=0.454$ \\
\hline Between treatments & 0.002 & 2 & 0.001 & \\
\hline Within treatment & 0.085 & 36 & 0.0024 & \\
\hline Total & 0.088 & 38 & & \\
\hline
\end{tabular}

$*$ The f-ratio value is 0.454 . The $p$-value is 0.639 . The result is not significant at $p<0.05$.

Table 7. SSD specific gravity of fine RVA and CLA

\begin{tabular}{|c|c|c|c|c|c|c|c|c|}
\hline \multicolumn{4}{|c|}{ RVA } & \multicolumn{3}{c|}{ CLA/Karak } & \multicolumn{3}{c|}{ CLA/Tafila } \\
\hline Average & Std. & $\mathrm{N}$ & Average & Std. & $\mathrm{N}$ & Average & Std. & $\mathrm{N}$ \\
\hline 2.468 & 0.048 & 13 & 2.683 & 0.057 & 11 & 2.546 & 0.078 & 11 \\
\hline
\end{tabular}


Table 8. Statistical data and calculation for apparent specific gravity of fine RVA

\begin{tabular}{|c|c|c|c|c|}
\hline Statistical parameters & Right & Mid & Left & Total \\
\hline $\mathrm{N}$ & 13 & 13 & 13 & 39 \\
\hline$\Sigma \mathrm{x}$ & 34.442 & 34.290 & 34.578 & 103.310 \\
\hline Mean & 2.649 & 2.638 & 2.660 & 2.649 \\
\hline$\Sigma \times 2$ & 91.292 & 90.457 & 92.178 & 273.927 \\
\hline Standard Deviation & 0.060 & 0.032 & 0.031 & 0.083 \\
\hline \multicolumn{5}{|c|}{ Results details } \\
\hline Source & SS & df & MS & $\mathrm{F}=0.222$ \\
\hline Between treatments & 0.003 & 2 & 0.002 & \\
\hline Within treatment & 0.26 & 36 & 0.007 & \\
\hline Total & 0.263 & 38 & & \\
\hline
\end{tabular}

* The f-ratio value is 0.222 . The $\mathrm{p}$-value is 0.802 . The result is not significant at $\mathrm{p}<0.05$.

Table 9. Apparent specific gravity of fine RVA and CLA

\begin{tabular}{|c|c|c|c|c|c|c|c|c|}
\hline \multicolumn{3}{|c|}{ RVA } & \multicolumn{3}{c|}{ CLA/Karak } & \multicolumn{3}{c|}{ CLA/Tafila } \\
\hline Average & Std. & $\mathrm{N}$ & Average & Std. & $\mathrm{N}$ & Average & Std. & $\mathrm{N}$ \\
\hline 2.649 & 0.083 & 13 & 2.694 & 0.071 & 11 & 2.676 & 0.079 & 11 \\
\hline
\end{tabular}

Table 10. Statistical data and calculation for dry specific gravity of coarse RVA

\begin{tabular}{|c|c|c|c|c|}
\hline Statistical parameters & Right & Mid & Left & Total \\
\hline $\mathrm{N}$ & 13 & 13 & 13 & 39 \\
\hline$\Sigma \mathrm{x}$ & 29.657 & 29.525 & 30.427 & 89.609 \\
\hline Mean & 2.281 & 2.271 & 2.341 & 2.298 \\
\hline$\Sigma \times 2$ & 67.742 & 67.067 & 71.606 & 0.118 \\
\hline Standard Deviation & 0.084 & 0.032 & 0.181 & \\
\hline \multicolumn{5}{|c|}{ Results details } \\
\hline Source & SS & df & MS & F $=1.346$ \\
\hline Between treatments & 0.037 & 2 & 0.018 & \\
\hline Within treatment & 0.488 & 36 & 0.014 & \\
\hline Total & 0.525 & 38 & & \\
\hline
\end{tabular}

* The f-ratio value is 1.346 . The $p$-value is 0.273 . The result is not significant at $p<0.05$.

Table 11. dry specific gravity of coarse RVA and CLA

\begin{tabular}{|c|c|c|c|c|c|c|c|c|}
\hline \multicolumn{4}{|c|}{ RVA } & \multicolumn{3}{c|}{ CLA/Karak } & \multicolumn{3}{c|}{ CLA/Tafila } \\
\hline Average & Std. & $\mathrm{N}$ & Average & Std. & $\mathrm{N}$ & Average & Std. & $\mathrm{N}$ \\
\hline 2.298 & 0.118 & 13 & 2.645 & 0.079 & 11 & 2.506 & 0.068 & 11 \\
\hline
\end{tabular}

Karak, and CLA/Tafila) as presented in Table 11, they are significantly different depending on their means, standard deviation, and size of samples considering significance level $\alpha=0.05$. Each type of aggregate can be used significantly in concrete mix production. So, the null hypothesis $\mathrm{H} 0(\mu 1=$ $\mu 2=\mu 3)$ is rejected, and the alternate hypothesis Ha $(\mu 1 \neq \mu 2 \neq \mu 3)$ is accepted.

\section{Saturated surface dry specific gravity}

Table 12 presents the SSD specific gravity of coarse RVA that were collected from the valley. Results showed that samples' means are not significantly difference and all RVA are similar and representative to be used in concrete mix production.

Table 13 showed ANOVA analysis on the three groups of coarse aggregate samples (RVA, CLA /Karak, and CLA /Tafila). they are significantly different in means considering significance level $\alpha=0.05$. Each type of aggregate can be use significantly in concrete mix production. The null hypothesis $\mathrm{H} 0(\mu 1=\mu 2=\mu 3)$ is rejected, and the alternate hypothesis $\mathrm{Ha}(\mu 1 \neq \mu 2 \neq \mu 3)$ is accepted. 
Table 12. Statistical data and calculation for SSD specific gravity of coarse RVA

\begin{tabular}{|c|c|c|c|c|}
\hline Statistical parameters & Right & Mid & Left & Total \\
\hline $\mathrm{N}$ & 13 & 13 & 13 & 39 \\
\hline$\Sigma \mathrm{x}$ & 30.558 & 30.412 & 31.274 & 92.244 \\
\hline Mean & 2.351 & 2.339 & 2.406 & 2.365 \\
\hline$\Sigma \times 2$ & 71.918 & 71.156 & 75.652 & 218.725 \\
\hline Standard Deviation & 0.083 & 0.031 & 0.186 & 0.119 \\
\hline \multicolumn{5}{|c|}{ Results details } \\
\hline Source & SS & df & MS & F $=1.157$ \\
\hline Between treatments & 0.033 & 2 & 0.016 & \\
\hline Within treatment & 0.509 & 36 & 0.014 & \\
\hline Total & 0.542 & 38 & &
\end{tabular}

* The f-ratio value is 1.157 . The $p$-value is 0.326 . The result is not significant at $p<0.05$.

Table 13. SSD specific gravity of coarse RVA and CLA

\begin{tabular}{|c|c|c|c|c|c|c|c|c|}
\hline \multicolumn{3}{|c|}{ RVA } & \multicolumn{3}{c|}{ CLA/Karak } & \multicolumn{3}{c|}{ CLA/Tafila } \\
\hline Average & Std. & $\mathrm{N}$ & Average & Std. & $\mathrm{N}$ & Average & Std. & $\mathrm{N}$ \\
\hline 2.365 & 0.119 & 13 & 2.663 & 0.076 & 11 & 2.556 & 0.073 & 11 \\
\hline
\end{tabular}

\section{Apparent specific gravity}

Table 14 presents the apparent specific gravity of coarse RVA that were collected from the valley among 13 stations of overall 39 samples. Results showed that there is no difference between means of samples. So, samples of RVA are representative to be used in concrete mix.

By applying ANOVA analysis on the three groups of coarse aggregate samples (RVA, CLA / Karak, and CLA/Tafila), they are significantly different considering significance level $\alpha=0.05$. So, the null hypothesis Ho $(\mu 1=\mu 2=\mu 3)$ is rejected, and the alternate hypothesis $\mathrm{Ha}(\mu 1 \neq \mu 2 \neq \mu 3)$ is accepted. Table 15 showed the required results.

\section{Fineness modulus of RVA}

Table 16 presents the statistical calculations for the fineness modulus of the RVA for the 39 samples from the 13 stations that extend from right, middle, left sides of the valley. Results showed that fineness modulus has no difference between means of samples for RVA valley aggregate.

ANOVA analysis conducted on the three groups of coarse aggregate samples (RVA, CLA /Karak, and CLA / Tafila), they are significantly different considering significance level $\alpha=0.05$. So, the null hypothesis Ho $(\mu 1=\mu 2=\mu 3)$ is rejected, and the alternate hypothesis $\mathrm{Ha}(\mu 1 \neq \mu 2$ $\neq \mu 3)$ is accepted. Table 17 showed statistical parameters for ANOVA testing.

\section{Absorption of coarse RVA}

Table 18 presents the statistical calculations for the absorption of the coarse RVA for the 13 stations that extend from the right bank to the

Table 14. Statistical data and calculation for apparent specific gravity of coarse RVA

\begin{tabular}{|c|c|c|c|c|}
\hline Statistical parameters & Right & Mid & Left & Total \\
\hline $\mathrm{N}$ & 13 & 13 & 13 & 39 \\
\hline$\Sigma \mathrm{x}$ & 31.893 & 31.549 & 32.620 & 96.062 \\
\hline Mean & 2.453 & 2.427 & 2.509 & 2.463 \\
\hline $\mathrm{x} 2$ & 78.343 & 76.604 & 82.391 & 0.138 \\
\hline Standard Deviation & 0.092 & 0.056 & 0.212 & \\
\hline \multicolumn{5}{|c|}{ Results details } \\
\hline Source & SS & $\mathrm{df}$ & $\mathrm{MS}$ & $\mathrm{F}=1.222$ \\
\hline Between treatments & 0.046 & 2 & 0.023 & \\
\hline Within treatment & 0.678 & 36 & 0.019 & \\
\hline Total & 0.724 & 38 & & \\
\hline
\end{tabular}

* The f-ratio value is 1.222 . The $p$-value is 0.307 . The result is not significant at $\mathrm{p}<0.05$. 
Table 15. Apparent specific gravity of coarse RVA and CLA

\begin{tabular}{|c|c|c|c|c|c|c|c|c|}
\hline \multicolumn{3}{|c|}{ RVA } & \multicolumn{3}{c|}{ CLA/Karak } & \multicolumn{3}{c|}{ CLA/Tafila } \\
\hline Average & Std. & $\mathrm{N}$ & Average & Std. & $\mathrm{N}$ & Average & Std. & $\mathrm{N}$ \\
\hline 2.463 & 0.138 & 13 & 2.674 & 0.081 & 11 & 2.638 & 0.069 & 11 \\
\hline
\end{tabular}

Table 16. Statistical data and calculation for the fineness modulus of RVA

\begin{tabular}{|c|c|c|c|c|}
\hline Statistical parameters & Right & Mid & Left & Total \\
\hline $\mathrm{N}$ & 13 & 13 & 13 & 39 \\
\hline$\Sigma \mathrm{x}$ & 75.679 & 73.922 & 75.884 & 225.485 \\
\hline Mean & 5.822 & 5.686 & 5.837 & 5.782 \\
\hline$\Sigma \times 2$ & 440.863 & 421.792 & 443.047 & 1305.701 \\
\hline Standard Deviation & 0.157 & 0.348 & 0.090 & 0.231 \\
\hline \multicolumn{5}{|c|}{ Results details } \\
\hline Source & $\mathrm{SS}$ & $\mathrm{df}$ & $\mathrm{MS}$ & $\mathrm{F}=1.745$ \\
\hline Between treatments & 0.179 & 2 & 0.091 & \\
\hline Within treatment & 1.847 & 36 & 0.051 & \\
\hline Total & 2.026 & 38 & & \\
\hline
\end{tabular}

* The f-ratio value is 1.222 . The $p$-value is 1.892 . The result is not significant at $\mathrm{p}<0.05$.

Table 17. Fineness modulus of coarse RVA and CLA

\begin{tabular}{|c|c|c|c|c|c|c|c|c|}
\hline RVA & Std. & $\mathrm{N}$ & CLA /Karak & Std. & $\mathrm{N}$ & CLA /Tafila & Std. & $\mathrm{N}$ \\
\hline 5.78 & 0.23 & 13 & 5.26 & 0.19 & 11 & 5.842 & 0.18 & 11 \\
\hline
\end{tabular}

mid of the valley and the left bank of the valley. ANOVA analysis showed that samples' means of absorption for rounded and crushed aggregate are not significantly different and can be used in concrete mix as representative sample.

Also, ANOVA analysis as conducted on the three groups of coarse aggregate samples (RVA, CLA/Karak, and CLA/Tafila) to test the absorption of coarse aggregate, they are significantly different considering significance level $\alpha=0.05$. So, the null hypothesis Ho $(\mu 1=\mu 2=\mu 3)$ is rejected, and the alternate hypothesis $\mathrm{Ha}(\mu 1 \neq$ $\mu 2 \neq \mu 3)$ is accepted. Table 19 showed the conducted results.

ANOVA analysis was conducted on the absorption of the three groups of fine aggregate samples (VA, CLA /Karak, and CLA /Tafila), they are significantly different considering significance level $\alpha=0.05$. So, the null hypothesis Ho $(\mu 1=\mu 2=\mu 3)$ is rejected, and the alternative hypothesis $\mathrm{Ha}(\mu 1 \neq \mu 2 \neq \mu 3)$ is accepted. Table 20 showed the conducted results.

Table 18. Statistical data and calculation for the absorption of coarse RVA

\begin{tabular}{|c|c|c|c|c|}
\hline Statistical parameters & Right & Mid & Left & Total \\
\hline $\mathrm{N}$ & 13 & 13 & 13 & 39 \\
\hline$\Sigma \mathrm{x}$ & 0.373 & 0.394 & 0.375 & 1.142 \\
\hline Mean & 0.029 & 0.030 & 0.029 & 0.029 \\
\hline$\Sigma \times 2$ & 0.011 & 0.013 & 0.0113 & 0.035 \\
\hline Standard Deviation & 0.005 & 0.009 & 0.006 & 0.007 \\
\hline \multicolumn{7}{|c|}{ Results details } \\
\hline Source & SS & df & MS & F=0.233 \\
\hline Between treatments & 0.000 & 2 & 0.000 & \\
\hline Within treatment & 0.002 & 36 & 0.000 & \\
\hline Total & 0.002 & 38 & &
\end{tabular}

* The f-ratio value is 0.233 . The $\mathrm{p}$-value is 0.794 . The result is not significant at $\mathrm{p}<0.05$.

Table 19. Absorption of coarse RVA and CLA

\begin{tabular}{|c|c|c|c|c|c|c|c|c|}
\hline RVA & Std. & N & Karak CLA & Std. & N & Tafila CLA & Std. & N \\
\hline 0.021 & 0.007 & 13 & 0.023 & 0.0051 & 11 & 0.025 & 0.0046 & 11 \\
\hline
\end{tabular}


Table 20. Absorption of fine RVA and CLA

\begin{tabular}{|c|c|c|c|c|c|c|c|c|}
\hline RVA & Std. & N & Karak CLA & Std. & N & Tafila CLA & Std. & N \\
\hline 0.015 & 0.004 & 13 & 0.026 & 0.0046 & 11 & 0.027 & 0.0053 & 11 \\
\hline
\end{tabular}

\section{Aggregate impact value}

Aggregate impact value test (AIV) [31] was applied on RVA and CLA of Tafila and Karak areas. Table 20 shows the statistical parameters of the test on types of aggregate. The means of the three groups of aggregate samples (RVA, CLA / Karak, and CLA /Tafila) are significantly different considering significance level $\alpha=0.05$. So, the null hypothesis $\operatorname{Ho}(\mu 1=\mu 2=\mu 3)$ is rejected, and the alternate hypothesis $\mathrm{Ha}(\mu 1 \neq \mu 2 \neq \mu 3)$ is accepted. Results are presented in Table 21.

\section{Aggregate abrasion}

Aggregate abrasion is covered by [32] and conducted using Los Angeles machine. Test as applied on RVA and Karak and Tafila CLA. Table 22 showed the statistical parameters of the test. ANOVA analysis showed that the means of the three samples are significantly different considering significance level $\alpha=0.05$. The null hypothesis Ho $(\mu 1=\mu 2=\mu 3)$ is rejected, and the alternate hypothesis $\mathrm{Ha}(\mu 1 \neq \mu 2 \neq \mu 3)$ is accepted.

\section{Concrete properties}

\section{Slump of concrete mix}

Slump test is an important indicator on workability of concrete mix. The type and shape of aggregate have a great effect on mix workability. Slump test is applied under [33] specification. Table 23 presents slump value for RVA and CLA. ANOVA analysis showed that the means of the three samples of aggregate are significantly different considering significance level $\alpha=0.05$. So, the null hypothesis $\mathrm{Ho}(\mu 1=\mu 2=\mu 3)$ is rejected, and the alternative hypothesis $\mathrm{Ha}(\mu 1 \neq \mu 2 \neq \mu 3)$ is accepted. Slump test was applied for 15, 20, and $25 \mathrm{MPa}$ grades of concrete mix.

\section{Density of concrete}

Density of concrete is an indicator on the mass, weight, and strength of concrete. Density test is covered by [34]. density of concrete is measured on 7, 14, and on 28 day as shown in Table 23 for the concrete grades 15, 20, and $25 \mathrm{MPa}$. ANOVA analysis here is conducted on two-way of treatments that included the age of concrete and the type of aggregate. Results are significantly different for $15 \mathrm{MPa}$ and $20 \mathrm{MPa}$. While the results are not significantly different for $25 \mathrm{MPa}$ grade of concrete. Density of concrete gives significant difference considering the age of concrete and the type of aggregate. Table 24 showed the results of concrete density.

\section{Compressive strength of concrete}

Table 25 presents the compressive strength of concrete using RVA and CLA at 7-, 14-, and 28-day for the grades of concrete mix 15, 20, and $25 \mathrm{MPa}$. Compressive strength test is conducted according to [35]. Results of ANOVA analysis results showed that difference is significant for concrete compressive strength grades of 15 and $25 \mathrm{MPa}$. While difference is not significant in the compressive strength of crushed and round aggregate. The effect of age of concrete is significant for all grades of concrete. Also, grades of concrete gives significant difference considering type of aggregate for results.

\section{Tensile stress of concrete}

Table 26 presents the tensile stress of concrete using RVA and CLA at the main ages of concrete (7-, 14-, and 28-day) on concrete mix grades (15, 20 , and $25 \mathrm{MPa}$ ). Tensile strength of concrete is conducted according to [36] for testing cylindrical concrete specimens by splitting. ANOVA analysis was conducted on two-way of treatment,

Table 21. AIV of Coarse RVA and CLA statistical parameters

\begin{tabular}{|c|c|c|c|c|c|c|c|c|}
\hline RVA & Std. & N & Karak CLA & Std. & N & Tafila CLA & Std. & N \\
\hline 15.5 & 2.6 & 13 & 23 & 3.4 & 11 & 25 & 2.9 & 11 \\
\hline
\end{tabular}

Table 22. Abrasion value of Coarse RVA and CLA statistical parameters

\begin{tabular}{|c|c|c|c|c|c|c|c|c|}
\hline RVA & Std. & $\mathrm{N}$ & Karak CLA & Std. & $\mathrm{N}$ & Tafila CLA & Std. & $\mathrm{N}$ \\
\hline 18.5 & 3.7 & 13 & 27 & 3.4 & 11 & 29 & 4.1 & 11 \\
\hline
\end{tabular}


Table 23. Slump value of concrete mix produced using RVA and CLA, statistical parameters

\begin{tabular}{|c|c|c|c|c|c|c|c|c|}
\hline RVA & Std. & N & Karak CLA & Std. & N & Tafila CLA & Std. & N \\
\hline 180 & 3.21 & 6 & 152 & 3,16 & 6 & 150 & 2.65 & 6 \\
\hline \multicolumn{7}{|c|}{$20 \mathrm{MPa}$} \\
\hline 165
\end{tabular}

* For RVA and CLA at $15 \mathrm{MPa}$, the f-ratio value is 19.023. The p-value is 0.0024 . The result is significant at $\mathrm{p}<0.05$.

* For RVA and CLA at $20 \mathrm{MPa}$, the f-ratio value is 77.055. The p-value is 0.000022 . The result is significant at $p<0.05$.

* For RVA and CLA at $25 \mathrm{MPa}$, the f-ratio value is 70.335. The p-value is 0.000031 . The result is significant at $\mathrm{p}<0.05$.

Table 24. Density of concrete for RVA and CLA

\begin{tabular}{|c|c|c|c|c|c|c|c|c|c|c|}
\hline Age (days) & RVA & Std. & N & Karak CLA & Std. & N & Tafila CLA & Std. & N \\
\hline \multicolumn{8}{|c|}{$15 \mathrm{MPa}$} \\
\hline 7 & 2284 & 1.09 & 6 & 2296 & 10.15 & 6 & 2283 & 14.98 & 6 \\
\hline 14 & 2282 & 16.12 & 6 & 2289 & 13.89 & 6 & 2279 & 26.21 & 6 \\
\hline 28 & 2292 & 10.50 & 6 & 2294 & 4.51 & 6 & 2285 & 13.64 & 6 \\
\hline \multicolumn{8}{|c|}{$20 \mathrm{MPa}$} \\
\hline 7 & 2384 & 64.48 & 6 & 2398 & 11.59 & 6 & 2352 & 18.49 & 6 \\
\hline 14 & 2368 & 13.69 & 6 & 2389 & 47.72 & 6 & 2346 & 57.14 & 6 \\
\hline 28 & 2366 & 7.46 & 6 & 2394 & 57.81 & 6 & 2366 & 48.32 & 6 \\
\hline \multicolumn{7}{|c|}{$25 \mathrm{MPa}$} \\
\hline 7 & 2334 & 59.03 & 6 & 2384 & 27.39 & 6 & 2380 & 46.03 & 6 \\
\hline 14 & 2358 & 21.04 & 6 & 2378 & 58.05 & 6 & 2357 & 68.47 & 6 \\
\hline 28 & 2380 & 11.22 & 6 & 2361 & 24.54 & 6 & 2346 & 34.09 & 6 \\
\hline
\end{tabular}

* At all levels of treatments (age of concrete in days) and grade of concrete (15 MPa), for RVA and CLA, the result is significant at $\mathrm{p}<0.05$.

* For RVA and CLA at $20 \mathrm{MPa}$, the result is not significant $\mathrm{p}<0.05$.

* For RVA and CLA at $25 \mathrm{MPa}$, the result not significant $\mathrm{p}<0.05$.

Table 25. Density of concrete for RVA and CLA

\begin{tabular}{|c|c|c|c|c|c|c|c|c|c|c|}
\hline Age (days) & RVA & Std. & N & Karak CLA & Std. & N & Tafila CLA & Std. & N \\
\hline \multicolumn{7}{|c|}{$15 \mathrm{MPa}$} \\
\hline 7 & 11 & 0.173 & 6 & 13 & 0.701 & 6 & 13 & 0.11 & 6 \\
\hline 14 & 14 & 0.175 & 6 & 15 & 0.521 & 6 & 14 & 0.301 & 6 \\
\hline 28 & 17 & 0.396 & 6 & 18 & 0.51 & 6 & 17 & 0.178 & 6 \\
\hline \multicolumn{7}{|c|}{$20 \mathrm{MPa}$} \\
\hline 7 & 14 & 0.138 & 6 & 16 & 0.551 & 6 & 14 & 0.18 & 6 \\
\hline 14 & 18 & 0.476 & 6 & 21 & 0.34 & 6 & 19 & 0.143 & 6 \\
\hline 28 & 22 & 0.229 & 6 & 25 & 0.666 & 6 & 23 & 0.175 & 6 \\
\hline \multicolumn{7}{|c|}{$25 \mathrm{MPa}$} \\
\hline 7 & 18 & 0.222 & 6 & 21 & 0.436 & 6 & 19 & 0.136 & 6 \\
\hline 14 & 22 & 0.221 & 6 & 24 & 0.333 & 6 & 23 & 0.138 & 6 \\
\hline 28 & 26 & 0.221 & 6 & 28 & 1.341 & 6 & 27 & 0.138 & 6 \\
\hline
\end{tabular}

* At all level of treatments (age of concrete in days) and grade of concrete $15 \mathrm{MPa}$, for RVA and CLA, the result is significant at $\mathrm{p}<0.05$.

* For RVA and CLA at $20 \mathrm{MPa}$, the result is not significant at $\mathrm{p}<0.05$.

* For RVA and CLA at $25 \mathrm{MPa}$, the result is significant at $\mathrm{p}<0.05$.

and results showed that the difference is significant for the concrete grades 15 and $25 \mathrm{MPa}$. While, difference is not significant for results on the concrete grades. Difference according to the effect of age of concrete is significant for all concrete grades. 
Table 26. Tensile strength of concrete made of RVA and CLA

\begin{tabular}{|c|c|c|c|c|c|c|c|c|c|c|}
\hline Age (days) & RVA & Std. & N & Karak CLA & Std. & N & Tafila CLA & \multicolumn{2}{|c|}{ Std. } & N \\
\hline \multicolumn{8}{|c|}{$15 \mathrm{MPa}$} \\
\hline 7 & 1.19 & 0.05 & 6 & 1.35 & 0.05 & 6 & 1.27 & 0.045 & 6 \\
\hline 14 & 1.51 & 0.032 & 6 & 1.71 & 0.05 & 6 & 1.64 & 0.064 & 6 \\
\hline 28 & 1.68 & 0.068 & 6 & 1.98 & 0.032 & 6 & 1.82 & 0.068 & 6 \\
\hline \multicolumn{8}{|c|}{$20 \mathrm{MPa}$} \\
\hline 7 & 1.46 & 0.047 & 6 & 1.67 & 0.021 & 6 & 1.54 & 0.026 & 6 \\
\hline 14 & 1.89 & 0.038 & 6 & 2.06 & 0.015 & 6 & 1.95 & 0.01 & 6 \\
\hline 28 & 2.08 & 0.057 & 6 & 2.42 & 0.05 & 6 & 2.28 & 0.038 & 6 \\
\hline \multicolumn{7}{|c|}{$25 \mathrm{MPa}$} \\
\hline 7 & 2.23 & 0.085 & 6 & 2.38 & 0.031 & 6 & 2.33 & 0.031 & 6 \\
\hline 14 & 2.37 & 0.04 & 6 & 2.59 & 0.02 & 6 & 2.43 & 0.026 & 6 \\
\hline 28 & 2.58 & 0.144 & 6 & 2.78 & 0.142 & 6 & 2.62 & 0.172 & 6 \\
\hline
\end{tabular}

* At all levels of treatments (age of concrete in days) and grade of concrete $15 \mathrm{MPa}$, for RVA and CLA, the result is significant at $\mathrm{p}<0.05$.

* For RVA and CLA at $20 \mathrm{MPa}$, the result is not significant at $\mathrm{p}<0.05$.

* For RVA and CLA at $25 \mathrm{MPa}$, the result is significant at $\mathrm{p}<0.05$.

Table 27. Modulus of rupture of concrete made of RVA and CLA

\begin{tabular}{|c|c|c|c|c|c|c|c|c|c|c|}
\hline Age (days) & RVA & Std. & N & Karak CLA & Std. & N & Tafila CLA & Std. & N \\
\hline \multicolumn{8}{|c|}{$15 \mathrm{MPa}$} \\
\hline 7 & 1.99 & 0.032 & 6 & 2.19 & 0.023 & 6 & 2.09 & 0.042 & 6 \\
\hline 14 & 2.35 & 0.038 & 6 & 2.7 & 0.031 & 6 & 2.53 & 0.046 & 6 \\
\hline 28 & 2.62 & 0.04 & 6 & 2.91 & 0.081 & 6 & 2.76 & 0.015 & 6 \\
\hline \multicolumn{8}{|c|}{$20 \mathrm{MPa}$} \\
\hline 7 & 2.48 & 0.023 & 6 & 2.88 & 0.1 & 6 & 2.75 & 0.06 & 6 \\
\hline 14 & 3.1 & 0.04 & 6 & 3.64 & 0.123 & 6 & 3.38 & 0.03 & 6 \\
\hline 28 & 3.53 & 0.051 & 6 & 3.96 & 0.127 & 6 & 3.77 & 0.06 & 6 \\
\hline \multicolumn{7}{|c|}{$25 \mathrm{MPa}$} \\
\hline 7 & 4.01 & 0.127 & 6 & 6.09 & 0.17 & 6 & 5.94 & 0.25 & 6 \\
\hline 14 & 6.62 & 0.24 & 6 & 7.06 & 0.199 & 6 & 6.79 & 0.12 & 6 \\
\hline 28 & 7 & 0.52 & 6 & 8.1 & 0.22 & 6 & 7.05 & 0.18 & 6 \\
\hline
\end{tabular}

* At all levels of treatments (age of concrete in days) and grade of concrete $15 \mathrm{MPa}$, for RVA and CLA, the result is significant at $\mathrm{p}<0.05$.

* For RVA and CLA at $20 \mathrm{MPa}$, the result is not significant at $\mathrm{p}<0.05$.

* For RVA and CLA at $25 \mathrm{MPa}$, the result is significant at $\mathrm{p}<0.05$.

\section{Modulus of rupture}

Table 27 presents the modulus of rupture for concrete using RVA and CLA on concrete mix grades $(15,20$, and $25 \mathrm{MPa})$. Test of modulus of rupture for concrete was conducted according to [37]. ANOVA analysis applied on two-way process for the age of concrete and the aggregate type the concrete was made of. Results showed that the difference is significant for 15 and 25 MPa for type of aggregate. While, results are not significant for the concrete grade $25 \mathrm{MPa}$ considering type of aggregate. And the effect of age of concrete, the difference is significant on the modulus of rupture for all grades of concrete.

\section{CONCLUSIONS}

According to ANOVA analysis that was conducted on the properties of RVA and CLA aggregate and on concrete mix, the study found that RVA has no significant difference on their aggregate properties or concrete properties. While the properties of RVA and CLA from Karak and Tafila sources are significantly different for fine and coarse aggregates. Results of slump value for fresh concrete mixes showed that there is significant difference between values of slumps on 15, 20, and $25 \mathrm{MPa}$ grades of concrete. There were a significant difference in means for 
hardened concrete mixes for density, compressive strength, tensile stress, and modulus of rupture at 15 and $25 \mathrm{MPa}$ concrete grades at 7, 14, and 28 day age of concrete. While, there is no significant difference between these properties at $20 \mathrm{MPa}$ concrete grade.

\section{REFERENCES}

1. Al-Baijat H. and Sarireh, M. The use of fine blast furnace slag in improvement of properties of concrete. Open Journal of Civil Engineering, 9(2), 2019, 95-105.

2. Sarireh, M. Examining the suitability of Tripoli as admixture in cement paste. International Journal of Construction Management. 2 November 2020.

3. Diamantonis, N. and Marinos I. Investigations about the influence of fine additives on the viscosity of cement paste for self-compacting concrete. Construction and Building Materials, 1518, 2010, 1522-1524.

4. Hafizah, N, and Khalid, A. Evaluation of effectiveness of methyl methacrylate as retarder additive in polymer concrete. Construction and Building Materials, 449, 2015, 456-493.

5. Chen WF. The civil engineering handbook. Florida: CRC Press, 1995.

6. Uluçayl M. New developments for asphaltic mixture design gyratory shear press. Ankara: YTMK; 1997. (in Turkish).

7. Sarireh, M. Concrete mix construction using local materials in Karak and Tafila area. International Conference for Capacity Building and Poverty Alleviation and Development, American University, Dubai, 26-28/5/2015.

8. Hachani, M.I., Kriker, A., Seghiri, M. Experimental study and comparison between the use of natural and artificial coarse aggregate in concrete mixture. International Conference on Technologies and Materials for Renewable Energy, Environment and Sustainability, TMREES'17, 21-24 April 2017, Beirut, Lebanon.

9. Namdar, A. Natural minerals mixture for enhancing concrete compressive strength. Fractured Integrità Strutturale, 22, 2012, 26-30; DOI: 10.3221/IGFESIS.22.04.

10. Walpole, R.E., Myers, R.H., Myers, S.L., Keying, Y. Probability and statistics for engineers and scientists, 8th edition. Prentice Hall, 2009.

11. ASTM C150/C150M - 19a. 2019. Standard specification for Portland cement: https://www.astm.org/ Standards/C150 [accessed on Feb., 11, 2021].

12. ASTM C1157, Standard performance specification for hydraulic cement. ASTM International.
13. Lafarge Jordanian Cement Company Website. Accessed at the link: https://www.lafarge.com.jo/ sites/jordan/files/documents/Rasikh-ar_0.pdf on 10/3/2019 11:20 pm.

14. Sarireh, M. High strength concrete using basalt aggregate in concrete mix improvement. The International Academic Cluster Conference '2017, Bangkok, Thailand, 5-6 October 2017.

15. General Specifications for Civil Engineering Works, Section 16, Concrete and Joints in Concrete: http:// www.cedd.gov.hk/eng/publications/standards handbooks_cost/doc/stan_gs_2006/gs_20006_doc/ Section_16_2006Edition_Concrete_26Feb07.pdf, 2006 Edition.

16. Sarireh, M. and Al-Baijat H. Local aggregate in production of concrete mix in Jordan. Open Journal of Civil Engineering, 9(2), 2019, 81-94.

17. Polat, R., Mehrzad M., Yadollahi, A. Emre S., Seracettin A. The correlation between aggregate shape and compressive strength of concrete: Digital image processing approach. Int. J. Struct. \& Civil Eng. Res. 2013.

18. Sarireh, M. The use of local materials crushed and rounded aggregate in Tafila and Karak areas in concrete production. Conference Poverty Alleviation Through Projects '2015, American University, Dubai, United Arab Emirates, 25-28/5/2015.

19. ACI Committee 211, Standard practice for selecting proportions for normal, heavyweight and mass concrete. ACI211.1-91, American Concrete Institute, Farmington Hills, Michigan 1991.

20. ACI Committee 211, Guide for selecting proportions for no-slump concrete. ACI 211.3R-97, American Concrete Institute, Farmington Hills, Michigan, 1997.

21. BS 882: 1992, Specification for aggregates from natural resources for concrete.

22. ASTM C136 / C136M-19. 2019. Standard test method for sieve analysis of fine and coarse aggregates. ASTM International, West Conshohocken, PA. Available from: https://www.astm.org/Standards/C136.htm [accessed Feb., 11, 2020].

23. Sarireh, M. and Al-Baijat H. Cement-Tripoli admixture replacement in concrete mix. Electronic Journal of Geotechnical Engineering, 24, 2019, 2.

24. Al-Baijat H. and Sarireh, M. Concrete properties using Tripoli. Electronic Journal of Geotechnical Engineering, 24, 2019, 2.

25. Binici, H., Sbah, T., Aksogan, O., Kaplan, H. Durability of concrete made with granite and marble as recycle aggregates. J. Material Processing Technology, 208(1), 2008, 299-308.

26. ASTM C192/C192M. 2014. Standard practice for making and curing concrete test specimens in the laboratory: https://www.astm.org/database.cart/historical/C192C192M-14.htm [accessed on Feb. 11, 2021]. 
27. Neville A.M. 1995. Properties of concrete. 5th Ed. Pearson Education Limited Edinburgh Gate, Harlow, Essex CM20 2JE, England, pp. 676.

28. Ahmad, S. and Alghamdi, S.A. (2014). A statistical approach to optimizing concrete mixture design. The Scientific World Journal, 2014.

29. Sarireh, M., Najafi, M., Chien-Pai H. ANOVA analysis applied in studding factors related to HDD productivity. Journal of Pipeline Systems Engineering and Practices. ASCE, 2012.

30. Sarireh, M., Najafi, M., Slavin, L. Factors affecting productivity of horizontal directional drilling. ICPTT, 2012, 1848-1858.

31. ASTM C131 / C131M-20, Standard test method for resistance to degradation of small-size coarse aggregate by abrasion and impact in the Los Angeles machine. ASTM International, West Conshohocken, PA, 2020, www.astm.org

32. ASTM C535-16, Standard test method for resistance to degradation of large-size coarse aggregate by abrasion and impact in the Los Angeles ma- chine. ASTM International, West Conshohocken, PA, 2016, www.astm.org

33. ASTM C143 / C143M-20, Standard test method for slump of hydraulic-cement concrete. ASTM International, West Conshohocken, PA, 2020, www.astm.org

34. ASTM C138 / C138M-17a, Standard test method for density (unit weight), yield, and air content (gravimetric) of concrete. ASTM International, West Conshohocken, PA, 2017, www.astm.org [accessed April 7 2021].

35. ASTM C39/C39M-21. Standard test method for compressive strength of cylindrical concrete specimens and compressive strength of concrete cubes.

36. ASTM C496 / C496M-17, Standard test method for splitting tensile strength of cylindrical concrete specimens. ASTM International, West Conshohocken, PA, 2017, www.astm.org

37. ASTM C78 / C78M-21, Standard test method for flexural strength of concrete (using simple beam with third-point loading). ASTM International, West Conshohocken, PA, 2021, www.astm.org 